\title{
EXPERIMENTAL STUDY OF HYBRID RUBBERIZED COMPOSITE SLABS
}

\section{P. SUBASHREE ${ }^{1}$, R. THENMOZHI ${ }^{2}$}

Rubberized concrete is made up of scrap tyre rubbers where the fine aggregate is partially replaced by it, as the waste rubber is being a threat to the environment. It is estimated that only $4 \%$ of the waste tyre is used in the application of civil engineering and also there is shortage of fine aggregates. The primary objective of this study is to investigate the preliminary concrete properties of M25 and M30 concretes. The fine aggregate is replaced by pre-treated crumb rubber with 10, 15 and $20 \%$ of total weight. Various tests are conducted on the rubberized concrete specimens such as compressive strength, split tensile strength, flexural strength and slump test. The investigation is carried out to determine the impact load behavior of hybrid rubberized composite slabs. In addition $0 \%, 1 \%, 1.5 \%$, and $2 \%$ of replacement of rubber fibers for total weight of coarse aggregate is also made. The specimen of size $300 \mathrm{~mm} \times 300 \mathrm{~mm} \times 50 \mathrm{~mm}$ thickness is subjected to drop hammer test to find its performance against the impact loads. The number of blows for the first crack and complete failure of slab was found and the characteristics were studied.

Keywords: Crumb rubber, Rubberized concrete slab, Impact test, Energy absorption, Ductility Index.

\section{INTRODUCTION}

Waste handling and controlling is a very challenging and hectic problem all over the world. As per the statistical report from the agency of environmental protection, the waste tyre production crosses $270,000,000$ millions [1]. The dispatching of these wastes is of great concern to the environment [2]. In future these wastes are to be dumped into the bare lands but it causes many problems to the

\footnotetext{
${ }^{1}$ Eng., Research Scholar, Department of Civil Engineering, Anna University, Chennai, India, e-mail: subasri03@gmail.com

${ }^{2}$ Asso. Prof., Ph.D., Eng., Department of Civil Engineering, Government College of Technology, Coimbatore -641013 , India.
} 
environment. Instead recycling of waste tyres can be done [3]. Some of the choices are: reuse of ground tyre rubers in a variety of plastic and rubber products, tyre retreating applications, crash barriers, highways and breakwaters, but after this usage the material becomes scrap and the search of recycling draw out. Concrete Structure is designed for service life 50 to 100 years, which promotes the usage of waste tyre rubber as a constituent material in concrete which gives sustainable result to the problem faced $[4,5]$. On the other hand the infrastructure development results in excessive use of natural aggregate [6,7]. To cope up with the increasing demand of natural fine aggregates, the rate of extraction is also being increased. Natural aggregate extraction from lakes, river beds, etc results in huge impact on the environment such as flooding, landslides, etc. [8,9]. Also the rainwater filteration carried out by deposits of natural sand is completely lost. To reduce these problems, the waste tyre rubbers are replaced partially for the natural aggregates $[10,11,12]$.The concrete manufactured by scrap rubber as a fractional replacement is called as Rubberized concrete $[13,14,15,16]$. Suitability of such material is identified by various researches $[17,18,19]$.

\section{MATERIAL INVESTIGATION}

Cement: In this work, OPC Cement of 53 grade is used. The physical properties of cement are obtained by conducting the specified tests as per the IS standards, namely IS 1727:1967 and IS

\begin{tabular}{|c|l|c|}
\hline S.NO. & \multicolumn{1}{|c|}{ PROPERTIES } & VALUES \\
\hline 1 & Specific gravity of coarse & 2.72 \\
\hline 2 & Water absorption & $1 \%$ \\
\hline 3 & Fineness modulus & 4.72 \\
\hline 4 & Aggregate Impact test value & $13.58 \%$ \\
\hline 5 & Aggregate Crushing value & $18.24 \%$ \\
\hline
\end{tabular}

4031(Part - 5):1988 and the values are shown in Table 1.

Fine Aggregate: According to the grading zone II the locally available sand is used for experimental works. The specific gravity and water absorption of fine aggregate as per IS: 2386 (Part3) - 1963 were found to be 2.62 and 2\% respectively. Sieve analysis of the fine aggregate was carried out in the laboratory as per IS383-1970 and the particle size distribution is shown in Fig.1.

Table.1 Physical Properties of Cement

\begin{tabular}{|c|l|c|}
\hline S. No. & \multicolumn{1}{|c|}{ PROPERTIES } & $\begin{array}{c}\text { VALUE } \\
\text { S }\end{array}$ \\
\hline 1 & Specific gravity of cement & 3.10 \\
\hline 2 & Fineness of cement & $4 \%$ \\
\hline 3 & Standard consistency of cement & $30 \%$ \\
\hline 4 & Initial setting time & $35 \mathrm{~min}$ \\
\hline 5 & Final setting time & $512 \mathrm{~min}$ \\
\hline \multirow{2}{*}{6} & Compressive strength of cement & 53.80 \\
& mortar in 28 days & MPa \\
\hline
\end{tabular}

Table.2.Properties of Coarse Aggregate 


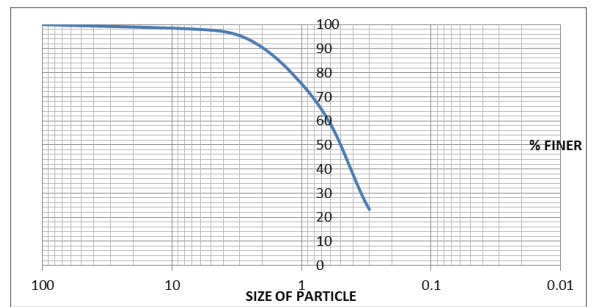

Fig.1 Particle Size Distribution for Sand

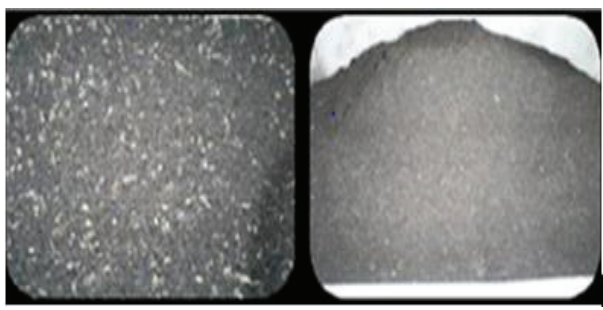

Fig. 2. Crumb Rubber Aggregate

Coarse Aggregate: The coarse aggregates which are locally available having the maximum size of $20 \mathrm{~mm}$ were used in the work. The following tests are carried out as per IS: 2386 (Part3) - 1963 and results are reported in Table.2.

Crumb Rubber Aggregate: The crumb rubber is the recycled rubber. In this study, the crumb rubber passing through the seive size of $2.36 \mathrm{~mm}$ is used for the partial substitute of fine aggregate. The rubber fibres used in this project having an aspect ratio ranging from 25- 30 is shown in Figure 2. The specific gravity and water absorption of rubber was found to be 1.3 and $1.3 \%$ respectively.

Chemical Solution: Acetic acid is an organic compound which has the chemical formula $\mathrm{CH}_{3} \mathrm{COOH}$. The rubber used in the concrete was immersed in the Acetic acid (5\% concentration) and kept undisturbed for 24 hours, then taken out, rinsed with water, dried and used in concrete manufacturing. The tap water with $\mathrm{pH} 6.5$ is used for mixing as well as curing purposes.

\section{PROPERTIES OF RUBBERIZED CONCRETE}

Mix Proportion: The mix proportions are made for the M25, M30, and M35 grades of concrete. Table 3 shows the calculated mix proportions.

Manufacturing of Rubberized Concrete: The ingredients needed for the concrete are weighed and are taken as per the mix proportions arrived from the mix design. Mixing is done with hand by using trowel after arriving the required materials. After the addition of each material, mixing was done until the mix became homogeneous. These mixture is filled and compacted manually using a damping rod in the oiled steel mould. After 24 hour of casting, the specimens are removed from the moulded and cured. 
Table 3 Mix Proportions of Concrete

\begin{tabular}{|c|c|c|}
\hline Grade of Concrete & $\begin{array}{c}\text { Mix Proportion } \\
\text { (Cement: FA : CA) }\end{array}$ & Water Cement Ratio \\
\hline M25 & $1: 1.46: 2.57$ & 0.45 \\
\hline M30 & $1: 1.15: 2.12$ & 0.38 \\
\hline M35 & $1: 1: 1.93$ & 0.35 \\
\hline
\end{tabular}

Fresh Concrete Properties: The slump test is made to find the workability of fresh concrete and the results are shown in Figure 3. The results indicated that there was an increase in slump value when crumb rubber content increased from $0 \%$ to $20 \%$. It means that with respect to the normal concrete, the workability rubberized concrete is acceptable in terms of placing, handling and finishing.

Hardened Concrete Properties: The compressive strength test revealed that the conventional concrete exhibited higher strength than the rubberized concrete. It was also revealed that the compressive strength reduced as the percentage replacement increased from 10 to $20 \%$. The tensile strength test revealed that the conventional concrete exhibited higher strength than the rubberized concrete. It was also revealed that the tensile strength reduced as the percentage replacement increased from 10 to $20 \%$. On comparing the flexural strength of conventional concrete with rubber replaced concrete, the flexural strength was raised by increasing the treated rubber content.

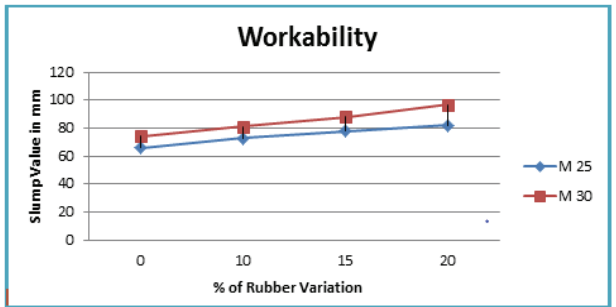

Fig.3.Slump Value of Conventional and Rubberized Concrete

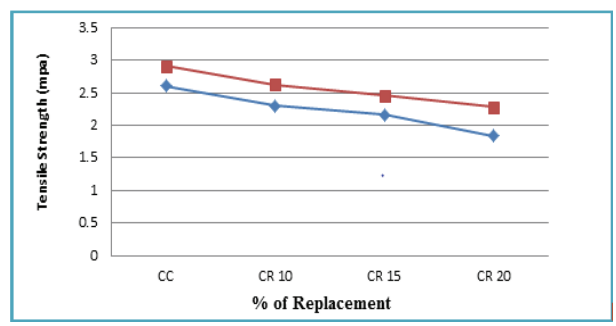

Fig.5.Tensile Strength of Conventional and Rubberized Concrete

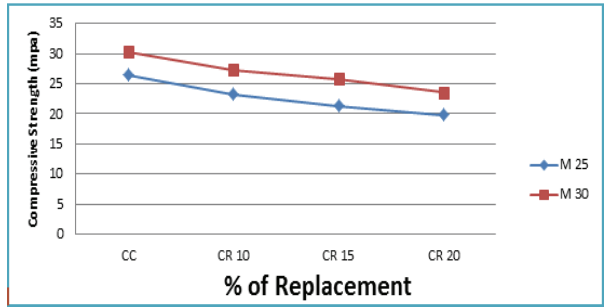

Fig.4.Compressive Strength of Conventional and Rubberized Concrete

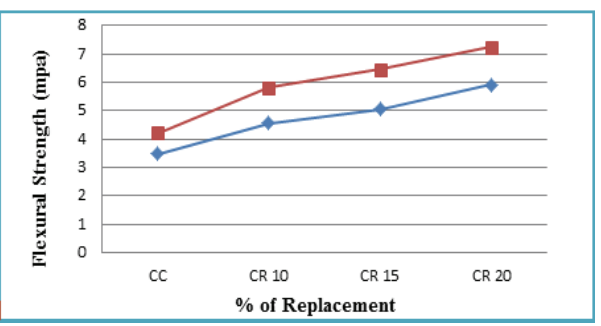

Fig.6.Flexural Strength of Conventional and Rubberized Concrete 


\section{HYBRID RUBBERIZED COMPOSITE SLABS}

Hybridized rubber concrete consists of two layers with rubber concrete on the top layer and at bottom plain concrete is placed. Since rubber concrete has greater potential to absorb impact loads, it is kept on the top layer and simultaneously plain concrete, which has greater resistance to tension (when compared with rubberized concrete) is kept in the bottom layer to get better results.

Casting and Curing of HRC Slabs: A total of 45 slabs was cast with three different mix proportions (M25, M30, M35 ) with varying fibre content $(0.5 \%, 1 \%, 1.5 \%, 2 \%)$. Out of these 45 cubes, 9 were ordinary concrete slabs (OC) and remaining are Hybrid Rubberized concrete slabs (HRC). Figure 7,8 and 9 shows the wet mix, casted specimens and cured specimens respectively.

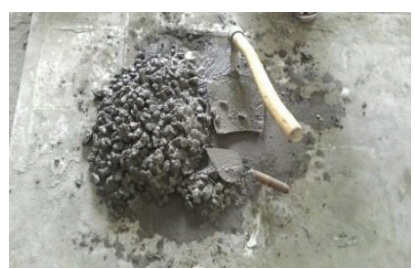

Fig.7.Wet mix

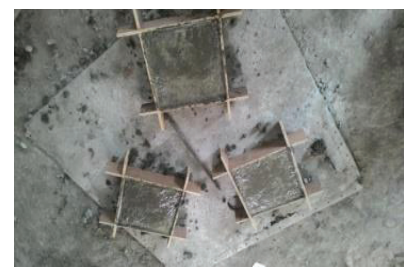

Fig. 8. Specimens after casting

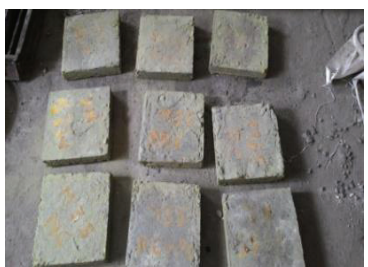

Fig 9.Specimens after curing

Rebound hammer test: The compressive strength of concrete slab is found using rebound hammer test. It has a plunger which has to be pressed perpendicular against the concrete slab and until the hammer impacts, the pressure is applied gradually. Before the test, the hammer was tested against the test anvil, to get reliable results.

Drop hammer test: The impact loads are tested using a well-known test called drop hammer test. The drop hammer apparatus is supported by short columns and consist of rigid welded steel frame square in plan. It has a mass of $3.5 \mathrm{~kg}(34.335 \mathrm{~N})$ and the hammer is dropped from constant height $(1.20 \mathrm{~m})$ on the specimen. The test setup consists of a cylindrical ball of $90 \mathrm{~mm}$ diameter and $80 \mathrm{~mm}$ height with hemispherical blunt tip to a height of $20 \mathrm{~mm}$, which acts as a plunger. For each specimen, the hammer is dropped and the number of blows for the first crack and the blows for final failure was recorded.

The specimens after curing are tested for its compressive strength and energy absorption. The results are tabulated in Table 4. 
Table 4. Compressive Strength Results

\begin{tabular}{|c|c|c|c|c|c|c|c|}
\hline \multirow[b]{2}{*}{ S.No } & \multirow{2}{*}{ Type of slab } & \multicolumn{2}{|r|}{ M25 } & \multicolumn{2}{|r|}{ M30 } & \multicolumn{2}{|r|}{ M35 } \\
\hline & & $\begin{array}{l}\text { Slab } \\
\text { ID }\end{array}$ & $\begin{array}{c}\begin{array}{c}\text { Compressive strength } \\
\text { (Mpa) }\end{array} \\
\end{array}$ & $\begin{array}{l}\text { Slab } \\
\text { ID }\end{array}$ & $\begin{array}{c}\text { Compressive strength } \\
\text { (Mpa) }\end{array}$ & \begin{tabular}{|l|} 
Slab \\
ID
\end{tabular} & $\begin{array}{c}\text { Compressive strength } \\
\text { (Mpa) }\end{array}$ \\
\hline 1 & \multirow{3}{*}{$\mathrm{OC}$} & A11 & 25 & B1 & 30 & $\mathrm{C} 1$ & 35 \\
\hline 2 & & A12 & 25 & B1 & 29 & $\mathrm{C} 1$ & 34 \\
\hline 3 & & A13 & 26 & $\mathrm{~B} 1$ & 30 & $\mathrm{C} 1$ & 35 \\
\hline 4 & \multirow{3}{*}{ HRC $(0.5 \%)$} & A21 & 22 & B2 & 26 & $\mathrm{C} 2$ & 31 \\
\hline 5 & & $\mathrm{~A} 22$ & 22 & $\mathrm{~B} 2$ & 26 & $\mathrm{C} 2$ & 32 \\
\hline 6 & & $\mathrm{~A} 23$ & 23 & $\mathrm{~B} 2$ & 25 & $\mathrm{C} 2$ & 31 \\
\hline 7 & \multirow{3}{*}{ HRC $(1.0 \%)$} & $\mathrm{A} 31$ & 20 & B3 & 24 & $\mathrm{C} 3$ & 29 \\
\hline 8 & & $\mathrm{~A} 32$ & 20 & B3 & 23 & $\mathrm{C} 3$ & 30 \\
\hline 9 & & A33 & 21 & B3 & 23 & $\mathrm{C} 3$ & 30 \\
\hline 10 & \multirow{3}{*}{$\operatorname{HRC}(1.5 \%)$} & A41 & 19 & B4 & 22 & $\mathrm{C} 4$ & 27 \\
\hline 11 & & A42 & 19 & B4 & 22 & $\mathrm{C} 4$ & 27 \\
\hline 12 & & A43 & 18 & B4 & 22 & $\mathrm{C} 4$ & 27 \\
\hline 13 & \multirow{3}{*}{ HRC $(2.0 \%)$} & A51 & 17 & B5 & 20 & $\mathrm{C} 5$ & 25 \\
\hline 14 & & A52 & 17 & B5 & 19 & $\mathrm{C} 5$ & 25 \\
\hline 15 & & A53 & 16 & $\overrightarrow{\mathrm{B} 5}$ & 20 & $\mathrm{C} 5$ & 25 \\
\hline
\end{tabular}

The results obtained from drop hammer test such as Energy absorption and ductility index were taken and compared $[20,21,22]$. The comparison is made between different types of slabs namely Ordinary concrete (OC), Hybrid Rubberized concrete (HRC) with four different rubber fibre content ranging from $0.5 \%$ to $2 \%$ and the results are shown in the fig 10 and 11 .

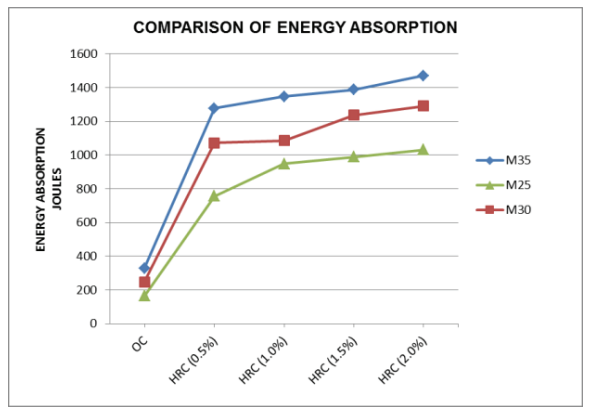

Fig. 10. Comparison of Energy Absorption

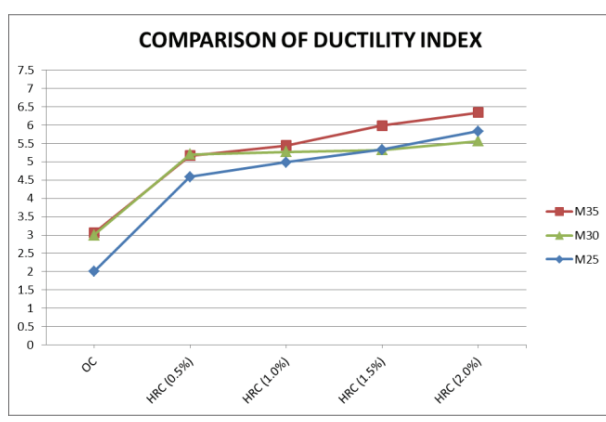

Fig 11. Comparison of Ductility Index

From fig. 10, it is clear that Hybrid Rubberized Concrete slabs with $2.0 \%$ rubber fibre content shows maximum energy absorption and the ordinary concrete shows low energy absorption. It is also noted that as the grade of concrete increases the energy absorption also increases and also in Hybrid Rubberized concrete slabs the energy absorption increases with increase in rubber fibre content. The energy absorption of HRC is 4 times greater than that of ordinary concrete in M25 grade and nearly 
5 times greater than ordinary concrete in M30 grade and 6 times greater than ordinary concrete in M35 grade.

From fig. 11 it is clear that Hybrid Rubberized Concrete slabs with $2.0 \%$ rubber fibre content shows maximum Ductility index and the ordinary concrete shows low Ductility Index and almost all Hybrid Rubberized concrete slabs with rubber fibres shows better ductility index. In Hybrid Rubberized concrete slabs the Ductility Index increases with increase in rubber fibre content.

\section{CONCLuSiON}

The results highlight positive effects on the flexural strength of concrete containing surface modified, recycled rubber when compared to concrete mixes of conventional concrete. Yet, the decrease in compressive, tensile strength with respect to conventional concrete is still evident. By the experimental investigations conducted on rubber concrete and the subsequent results, the following points can be concluded:

- The workability of fresh concrete is acceptable while adding the rubber aggregate to the concrete. This might be due to the lower water penetration capacity of the crumb rubber.

- The Compressive strength of rubberized concrete at $28^{\text {th }}$ day was decreased by $25.03 \%$ of conventional concrete.

- The tensile strength of rubberized concrete at $28^{\text {th }}$ day was also decreased by $29.50 \%$ of conventional concrete.

- But the flexural strength of rubberized concrete at $28^{\text {th }}$ day was increased by $41.38 \%$ of conventional concrete.

From the tests conducted on Hybrid Rubberized concrete slabs, it can be concluded that the fine aggregate replacement by optimum percentage of rubber is $10 \%$ and use acetic acid for the treatment of rubber is justified. By the performance of Hybrid rubber concrete slabs and the experimental results, the following conclusions were arrived.

- The tyres which are polluting the land by dumping can be efficiently used in civil engineering applications in the form of hybrid rubberized concrete.

- The hybrid rubberized slabs have better impact resistance and energy absorption than ordinary concrete.

- In hybrid rubberized concrete slabs with $2.0 \%$ rubber, showed higher energy absorption and ductility index and almost all hybrid rubberized concrete slabs with rubber fibres showed better results. 
The Hybrid Rubberized Concrete which has better performance can be used in places where the concrete surfaces are subjected to impact loads.

\section{REFERENCES}

1. P.V.Premalatha, A.Jennifer, S.Shree Janarthanan, "Utilization of Waste Tyre in Manufacturing of NonStructural Concrete", SECM/13/191, 4th International Conference on Structural Engineering and Construction Management, Kandy, Sri Lanka, 2013.

2. Santosh C. Jagadale, K.Rajkumar, R.P.Chavan, D.N.Shinde, C.L.Patil, "Environmental Concern of Pollution in Rubber Industry", International Journal of Research in Engineering and Technology, 4(11), 187-191, 2015.

3. Farrag Nermin Mokhtar, Ibrahim Vitta Abdel Rehim and Elalfy Ayman Mahmoud, "Applicability of using Recycled Rubber- Tire Materials for Acoustic Insulation in Barriers of Residential Areas in Egypt", ARPN Journal of Engineering and Applied Sciences, 12(3), 806 - 820, 2017.

4. Gideon Siringi, Ali Abolmaali, Pranesh B. Aswath, "Properties of Concrete with Tire Derived Aggregate Partially Replacing Coarse Aggregates”, The Scientific World Journal, 2015 (2015), Article ID 863706, 13 pages.

5. Xiang Shu, Baoshan Huang, "Recycling of Waste Tire Rubber in Asphalt and Portland Cement Concrete: An Overview", Construction and Building Materials, xxx, xxx-xxx, 1-8, 2013.

6. Alaa El-Din M. Sharkawi, Slah El-Din M. Almofty, Eng. Shady M. Abbass, "Performance of Green Aggregate Produced by Recycling Demolition Construction Wastes (Case Study of Tanta City)", Engineering, 8, 52-59, 2016.

7. Rahul M Jadhav, Pradip D Jadhao and Shantanu G Pande, “A Study on Behavior of Metakaolin Base Recycled Aggregate Concrete", International Journal of Structural and Civil Engineering Research, 4(1), 50-62, 2015.

8. Vishal Porwal, Ravi Dwivedi, "Studies on Tyre Aggregate Concrete with Fly Ash", International Journal of Science and Research, 5(8), 708-711, 2016.

9. Netravati Y Banasode, "Investigation Performance by Relatively Substitution of Cement and Coarse Aggregate by Fly ash and Waste Tire Rubber in Concrete", International Research Journal of Engineering and Technology, 4(10), 1615 - 1619, 2017.

10. Priyanka Asutkar, S.B.Shinde, RakeshPatel, "Study on the behaviour of rubber aggregates concrete beams using analytical approach", Engineering Science and Technology, An International Journal, 20(1), 151-159, 2017.

11. Mohd Kashif Khan, Bhanu Pratap Singh, "Used of Recycled Tyre/Rubber as Course Aggregate and Stone Dust as Fine Aggregate in Cement Concrete Works", IOSR Journal of Mechanical and Civil Engineering, 12 (5), 101$107,2015$.

12. Rahul Mahla , Er.R.P.Mahla, "Partial Replacement of Coarse Aggregate by Waste Tires in Cement Concrete", International Journal of Technical Research, 4(2), 95-98, 2015.

13. T. Senthil Vadivel \& R. Thenmozhi, "Experimental study on Waste Tyre Rubber Replaced Concrete - As Ecofriendly construction Material" Journal of Applied Science Research, 8(6), 2966 - 2973, 2012.

14. M. Mishra \& K.C. Panda, "An Experimental Study on Fresh and Hardened Properties of Self Compacting Rubberized Concrete" Indian Journal of Science and Technology, 8(29), 1-8, 2015.

15. S.M. Dumne, "An Experimental Study on performance of Recycled Tyre Rubber - Filled Concrete" International Journal of Engineering Research \& technology, 2(12), 766-772, 2013.

16. Saravanan \& A. Mansoor Ali, "Experimental Study on Concrete by Partial Replacement of Fine Aggregate with Crumb Rubber" International conference on Engineering Trends and Science \& Humanities, www.internationaljournalssrg.org, 60-65, 2015.

17. Er. YogenderAntil, “An Experimental Study on Rubberized Concrete” International Journal of Emerging Technology and Advanced Engineering, 4(2), 309-316, 2014.

18. T. SenthilVadivel, R. Thenmozhi \& M. Doddurani, "Experimental Behaviour of Waste Tyre Rubber Aggregate Concrete Under Impact Loading” IJST, Transaction of Civil Engineering, 38(C1), 251 - 259, 2014. 
19. Ahmed N. Bdour and Yahia A. Al- Khalayleh, "Innovative Application of Scrap-tire Steel Cords in Concrete Mixes" Jordan Journal of Civil Engineering, 4(1), 55-61, 2010.

20. Ganesan N, Bharati Raj J and Shashikala "Strength and Durability of Self-Compacting Rubberized Concrete", The Indian Concrete Journal, 15-24, 2012.

21. F. Hernandez-Olivares, G. Barluenga, "Fire Performance of Recycled Rubber-Filled High Strength Concrete" Cement and Concrete Research, 34, 109 -117, 2004.

22. Kotresh K M , Mesfingetahunbelachew, "Study on Waste Tyre Rubber as Concrete Aggregates" International Journal of Scientific Engineering and Technology, 3(4), 433-436, 2014.

\section{LIST OF FIGURES AND TABLES:}

Fig.1. Particle Size Distribution for Sand

Fig.2. Crumb Rubber Aggregate

Fig.3. Slump Value of Conventional and Rubberized Concrete

Fig.4. Compressive Strength of Conventional and Rubberized Concrete

Fig.5. Tensile Strength of Conventional and Rubberized Concrete

Fig.6. Flexural Strength of Conventional and Rubberized Concrete

Fig.7. Wet mix

Fig.8. Specimens after casting

Fig.9. Specimens after curing

Fig.10. Comparison of Energy Absorption

Fig.11. Comparison of Ductility Index

Tab. 1. Physical Properties of Cement

Tab. 2. Properties of Coarse Aggregate

Tab. 3. Mix Proportions of Concrete

Tab. 4. Compressive Strength Results 